\title{
American Christians for and against Parsifal: Debating the Holy Grail Opera in New York
}

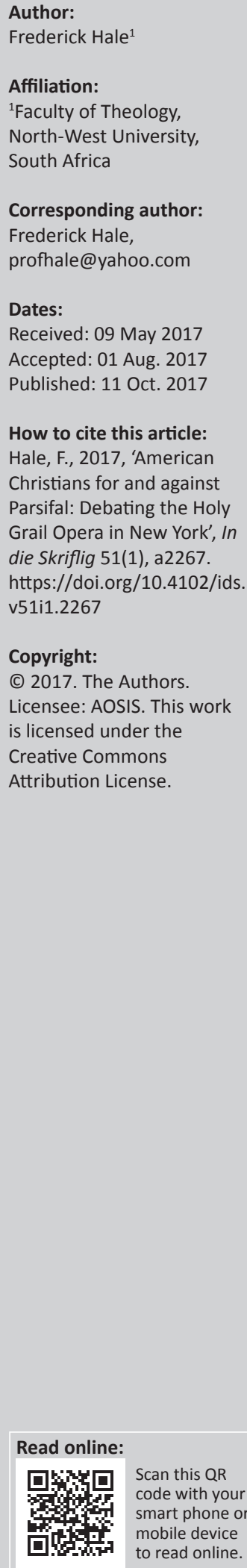

\begin{abstract}
The appropriateness of Christian themes in the performing arts has often been debated. Defenders have argued that various media, including drama, can serve as instruments of spiritual edification, while critics have contended that such efforts often eventuate in sacrilege and a vulgarising exploitation of the sacred for commercial and entertainment purposes. A heated debate took place in 1903 when Richard Wagner's opera Parsifal, which since its première at Bayreuth in 1882 had been hailed as a magnificent representation of redemption and other themes central to Christianity, was staged at the Metropolitan Opera House in New York - its first performance as an opera outside its original venue. Numerous clergymen and lay people in several denominations sought to have the production banned and cautioned fellow Christians against seeing it. Others, generally of a theologically more liberal bent, defended the work. The heated public controversy is placed into historical context and compared with the history of Parsifal in the United Kingdom, where it was widely appreciated without noteworthy opposition.
\end{abstract}

\section{Introduction}

Well over a century of international research on the notoriously controversial opera composer Richard Wagner (1813-1883) and his works has shed an enormous amount of light on his part in the stormy history of 19th-century music. Despite the mountain of research conducted in dozens of countries and languages, many corners of the general subject remain only dimly illuminated. Among these is the protracted controversy surrounding the watershed staging of his final opera, Parsifal, at New York's Metropolitan Opera House in 1903. This performance was the first of that opera as such (as opposed to it being sung as an oratorio) away from the purpose-built Festspielhaus in Bayreuth, which Wagner had explicitly demanded be its only home. At the time it was hailed as a milestone in the saga of Western music, as it made this controversial but already immensely popular work by one of the most disputed composers of all time available to a much wider audience than had been the case when its performance had been limited to Bayreuth. Echoing a popular sentiment at the time, the critic from the Boston Daily Globe went so far as to describe the performance as 'the most sensational event in American operatic history' (Anon 1903d:10). But it was more than an exorbitant performance which aroused national attention and filled the house repeatedly. As will be argued in the present article, this controversial undertaking also belongs to church history, broadly defined, and the debates surrounding it reveal something of the tenor of American Christianity in an era of rapid theological, cultural and social change.

The topic lies beyond the pale of what is generally included in general histories of Christianity in North America. Harold E. Briggs (1989) did not deal with specifically Christian responses to Parsifal in his useful study of Wagner's interaction with American musical and literary activity from 1850 onward. The renowned New York music critic Henry Edward Krehbiel (1854-1923) presented a one-sided view of those reactions in his history of lyric theatre in that city. Writing less than five years after the première, he remembered that 'a number' of clergymen - some of them 'of unquestioned sincerity' and others allegedly 'merely after notoriety' - had attacked Parsifal as sacrilegious. He did not go beyond these unsubstantiated allegations about unnamed men of the cloth. Readers are not informed that numerous church leaders actually had supported the production and engaged its foes in a heated and very public debate reported in newspapers across much of the country (Krehbiel 1908:331). Quaintance Eaton (1968) took the matter only slightly further in an 'informal' history of the Metropolitan Opera House, but reduced the religious debates to a caricature. Two camps opposing the production had supposedly arisen, bearing the labels 'Religion' and 'Law'. The former, according to Eaton, comprised ministers who 'took to their pulpits to denounce the "sacrilege"'. The only one whom he identified was an Episcopal bishop, Frederick Burgess (Eaton 1968:147). Relying heavily on flawed secondary literature, Joseph Horowitz continued the misunderstanding in his Wagner Nights: An American History. 
There one reads that in 1903 'outraged clergy', under the leadership of George L. Shearer of the American Tract Society, formed a 'swelling chorus' to protest against Parsifal (Horowitz 1994:262). In fact, Shearer was a minor player in this dispute whose leaders are identified below. Moreover, Horowitz failed to convey the considerable amount of clerical support for this opera. Lost in this crass caricature are the magnitude and nuances of a major controversy which carried serious weight in the minds of many concerned Christians. More detailed Wagner scholarship, such as the books about Parsifal by Beckett (1981) and Kinderman and Syer (2005), reveal virtually nothing about the debate.

The war of words, which was fought not only in the daily press but also in religious periodicals and in numerous public lectures and sermons, began months before Parsifal opened on Christmas Eve and spilled over into 1904. In many cities it was repeatedly front page news. Considered from the perspective of religious studies or church history, the public strife is particularly significant for numerous reasons. To begin with, divergent responses from churchmen across much of the denominational spectrum to the proposed performance revealed how agitated many clergymen across much of the country could become over what they perceived to be sacrilegious exploitation of a sacred theme for entertainment and commercial purposes. This lay at the heart of the debate but was only part of a larger set of issues. Foremost among these was the pivotal question whether Parsifal is a Christian work and, if so, to what extent it fitted criteria for that label - a matter which remained a bone of contention long after the embers of strife in Manhattan and elsewhere had grown cold. As a corollary to this, there was, inescapably, the central matter of the interpretation of symbolism - in this case the degree to which the eponymous central character can be interpreted as a Christ figure and whether the sombre grail ritual in the first act is a stylised but nevertheless unambiguous proxy for the Lord's Supper. Issues involving the relationships between government, on the one hand, and both the performing arts and religion on the other, also came into play. At the opposite pole in the spectrum of opinion, several prominent parsons of more liberal theological bent contended that, considered as a work of art whose symbolism lent itself to diverse opinions, Parsifal could provide serious, appreciative Christians with valuable nourishment for the development of their faith. The battle lines did not match denominational borders; within Presbyterian and Episcopal circles, for example, one could hear voices both condemning and lauding Parsifal and the decision to have its American première on Christmas Eve. Mirroring the debates involving Protestant clerical responses, Catholic priests and journalists failed to agree on this opera's spiritual merits or dangers.

All of this took place during a period of theological turbulence in American Protestantism generally. By the first quinquennium of the 20th century, controversies pitting theological modernism against guardians of orthodoxy had nearly reached their summit. Only a few years later the highly publicised and widely distributed 90 essays known as
The Fundamentals and written by 64 authors who represented many denominations were published. In 1920 this gave the broadly defined defence of conventional doctrines its name: fundamentalism (Hale 2013).

In the present article steps will be taken towards filling this lacuna in both Wagner scholarship and the historiography of American Christianity by analysing several aspects of the controversy surrounding the American première of Parsifal. After briefly considering antecedent Christian reactions to that opera in England for comparative purposes, a representative cross-section of Protestant and Catholic opinion will be explored - both before and after the curtain rose on Christmas Eve in 1903. This will encompass numerous churchmen and women in several denominations and pay particular attention to the grounds on which they either supported or opposed Parsifal as such and the setting in which it was first offered to American audiences. What kinds of people participated in the debate, and which side did they support? What does a study of the strife tell us about this highly noteworthy episode in the history of the relationship between Christianity and the arts during a pivotal era in American religious history? Were Christians able to make a perceptible impact on the phenomenon at hand?

Scholarly debates about the thematic content of Parsifal have raged for many decades and entailed such issues as the extent to which it is anti-Semitic, whether it reflects the influence of Schopenhauer on Wagner, and whether one can detect in his final opera the composer's interest in Buddhism. However fascinating they may be to some scholars, they were absent from the controversy in 1903 and therefore are not taken up here. Furthermore, this article is not a theological exploration of the content of Parsifal but is limited to the debates surrounding the first performances outside Germany which made it an internationally performed work.

\section{Parsifal: A thematic synopsis}

Wagner's final opera is too well known to justify a detailed recapitulation here, but a brief synopsis of its plot and major themes can facilitate understanding of the controversies among Christians surrounding its staging in New York. In crafting his drama, Wagner drew on a 13-century German epic poem, Parzifal, by Wolfran von Eschenbach about the quest for the Holy Grail - a theme which had resurfaced in several European literatures since the Middle Ages. The plot unfolds at a castle named Monsalvat, the home of the Knights of the Holy Grail, whose mission is to protect both the vessel which captured the blood of Christ at his crucifixion and the spear with which a Roman soldier pierced Jesus on the cross. The Holy Spear, however, has fallen into the possession of a foe, Klingsor. The King of the Grail Knights, Amfortas, has been wounded by that spear in his custody, and his perennially unhealed causes him to suffer without respite. The senior Knight of the Grail, Gurnemanz, thus serves at times as the de facto leader. Near Monsalvat resides a fallen woman, Kundry, whose temptations are a constant threat to the piety and moral purity of the knights within. Also nearby 
lives Klingsor, who was briefly at Montsalvat but has been expelled owing to impiety. He vengefully seeks to ensnare knights there into immorality, especially through the sexual charms of Flower Maidens who bathe nearby. Much of this lends itself to interpretation as symbolism, though hardly detailed allegory, of the condition of fallen humanity in the Christian tradition.

Then appears a naïve young man, Parsifal, armed with bow and arrow, who in blissful ignorance shoots a holy swan near Monsalvat. Gurnemanz witnesses this, admonishes the youth, who does not even know his own name and invites him into the building. They observe the solemn Holy Grail ritual over which the chronically ailing Amfortas presides, but the awed Parsifal does not participate in the accompanying love feast. The ritual is sometimes believed to symbolise communion, despite the absence of a priest and thus of consecration of the elements.

In the second act, Kundry tries without success to seduce the young Parsifal. Enraged by his reluctance to enter into a tryst with her, she curses him to a life of failing effort to find the Holy Grail. Klingsor throws his spear at Parsifal, but when it stops in mid-air above his head, he clutches and makes the sign of the cross with it, and departs.

In the third and final act, Parsifal returns to Montsalvat many years later as a knight in full armour. In the interim, he has sought the Holy Grail and defeated many foes. The now aged Gurnemanz only belatedly recognises him as the simple lad who had visited Montsalvat. He anoints Parsifal, whose feet Kundry washes - an action inescapably reminiscent of the washing of Jesus's feet in Luke 7:38 and John 12:3. It is Good Friday, and Parsifal baptises Kundry, absolving her of her sins. He orders the unveiling of the Holy Grail within the castle. Parsifal touches Amfortas with the Holy Spear, thus finally healing him. Kundry, now released from the curse which has been upon her, collapses in death. A white dove descends, hovering above Parsifal as the opera ends. In certain respects, the title character can be interpreted as a quasi-Christ figure, particularly because he brings redemption to both Amfortas and Kundry, although Wagner's intentions in this regard were frequently debated in the early history of the reception of Parsifal.

\section{Reactions in Britain for comparative contextualisation}

It should be emphasised that despite the prominent spiritual themes in Parsifal, it was not inevitable that its staging should provoke a storm of protest from religious quarters in a society with strong Christian traditions which had been divided by decades of theological controversy. For purposes of transatlantic comparison, it can be noted that in the United Kingdom, which also had a spectrum of denominations and where theological modernism had made noteworthy inroads, Parsifal was never nearly as controversial on religious (or other) grounds as in the United States of America. The piece certainly attracted notice in British cultural circles where, as Anne Dzamba Sessa has demonstrated, interest in Wagner had long been strong (Sessa 1979). Parsifal received much attention in the British daily and musical press beginning nearly a year before its initial performance at Bayreuth in July 1882. As early as September 1881 The Graphic in London announced the schedule of its performances the following summer (Anon 1881a:24). Moreover, readers of the British press learned the following month that the vocal score of Parsifal would soon be available for purchase - more than half a year before its first performance (Anon 1881b:3). Pilgrimages from Britain to Bayreuth soon became popular undertakings by culturally inclined Britons.

The prelude to Parsifal had been played at concerts in London and to a lesser extent elsewhere in the United Kingdom as early as October 1882 in Crystal Palace in south London (Anon 1882a:7). But these performances provided little stimulus to religious debate. Indeed, as the London correspondent of The Glasgow Herald lamented before the end of that year, 'The opera itself, owing to its dealings in deeply religious subjects, is never likely to be heard on the English stage' (Anon 1882b:8). As an oratorio, though, Parsifal was performed numerous times in British venues beginning in 1884, when one of London's most prominent choir directors, Joseph Barnby, arranged performances in the Royal Albert Hall. An unimpressed critic at The Sunday Times commented that the 'difficulty of representation' in such a venue limited its value. He also lamented that the likelihood of the work being done as an fully fledged opera in Britain was virtually nil: Wagner's widow adamantly opposed Parsifal being performed abroad, and 'so long as English Lord Chamberlains continue to hold orthodox views on the performance of religious operas', Britons would have to trek to Bayreuth to see Parsifal (Anon 1884b:7). Again, a correspondent - this one of The Belfast News-Letter - declared categorically 'that "Parsifal" will ever take a place in the music of our country is quite impossible. There are not the means for its frequent production, even if it suited public taste.' Furthermore, he opined that this opera even lacked passages which lent themselves to discrete performance, 'like the Bridal Song and march in "Lohengrin," or the march in "Tannhaeuser"' (Anon 1884a:7).

British Christians in various denominations published books about Wagner's last opera during the 1880s and 1890s. In 1888, for example, Alfred Gurney (1843-1898), a priest at St. Barnabas Church, a High Church Anglican parish in Pimlico, London completed his appreciative Parsifal, A Festival Play by Richard Wagner: A Study (Gurney 1888). Peter Taylor Forsyth (1848-1921), a Scottish Congregationalist minister who had studied in Germany and would emerge as one of the most prominent British theologians of the early twentieth century, included two lengthy lectures about religious dimensions in Wagner's works generally and Parsifal in particular in a series which he delivered in London in 1888 and subsequently published under the title Religion in Recent Art (Forsyth 1889). Interest continued strong in the next decade. Charles T. Gatty (1851-1928), an Anglican vicar's son who had converted to Roman Catholicism, published his The Sacred Festival-Drama 
of Parsifal in 1894 (Gatty 1894). Wagner's final opera also reportedly provided much grist for homiletical mills. As the music critic of The Times noted in 1884 (without, to be sure, explaining the basis of his observations), 'Sermons have been preached upon Parsifal, and religious persons have owned that they derived from it purer joy and greater edification than from many a sermon' (Anon 1884c:10).

By the time Parsifal was finally staged in London as an opera in 1914, whatever shock value it may have had was no longer in place. American Christian detractors, it seems, had stolen the thunder. The issues then raised in England were comparatively innocuous. For example, approximately a fortnight before the first performance, Miss C.A. Cannon (1914:9) wrote to The Times to inform readers that it was 'a religious drama, setting forth the mysteries of faith, of life and of death' and that its representation 'of redemption through the divine life incarnate' reflected 'the most holy mysteries of the Catholic faith'. Therefore, Cannon (1914) asked: What could be more appropriate than to request that ladies who attended performances of Parsifal wear mantillas, the traditional female head covering at a Catholic mass? ${ }^{1}$ Published reviews do not indicate that many heeded this advice, but the spiritual content of the opera was underscored in them. An anonymous critic from The Times remarked that Cannon's suggestion 'may seem to others typical of a view that would confine the influence of the opera within too narrow limits'. Thematically, Parsifal was not merely Catholic, he argued, but rather 'a great religious work' which could be meaningful to 'all shades of religious opinion'. To him, Wagner's final opera was 'the last artistic word of one of the greatest artists that have enlarged the spirit of man' (Anon 1914a:7).

Generally speaking, not many British Catholics appear to have had particular interest in Wagner, but the prominent Catholic periodical The Tablet carried a respectful obituary after his death. Citing an undocumented source, the anonymous author noted that to Wagner's devotees he was:

not only the renewer of the Opera, the most genial musician of all nations and times, but one of the deepest poets and thinkers, one of the most gifted heralds of culture, a high-priest and a prophet, we may say, of a new religion. (Anon 1883b:13-14)

\section{Parsifal in America before its première at the Metropolitan Opera House}

In the United States of America, one can trace a similar historical pattern of exposure to Parsifal. Already in 1882, Americans began to flock to Bayreuth to witness it. The day after its première there, The New York Times could report that 'America was largely represented at the performance' (Anon 1882d:3). As in Britain, such treks continued to be publicised for many years in the press. Hard on their heels came performances of the work's Prelude by orchestras. As early as

1.C.A. Cannon (London) to Editor, The Times, 15 January 1914, in The Times, 19 January 1914, p. 9.
November 1882, that is less than five months after the opera's official première in Bayreuth, German-born Walter Damrosch (1862-1950), who was emerging as America's most prominent Wagner interpreter, led what appears to have been the first North American performance of that segment at the Academy of Music in New York (Anon 1882c:4). Others soon followed in various American and Canadian cities. Then performances of selections of the music as oratorios took place. Again Damrosch was a noteworthy pioneer. The young conductor led the Oratorio Society in performing one at the Metropolitan Opera House in March 1886, but reviews were unenthusiastic and underscored how dependent the artistic success of Parsifal was on the interplay of music, scenery and action (Anon 1886a:2; 1886b:4). Critics remained largely silent on the thematic content, and there was no dispute about spiritual points. That was also true when the same piece was again performed as an oratorio at the Brooklyn Academy of Music in March 1890 under the direction of Anton Seidl (Anon 1890b:5). Indicative of the intensity of public interest, in the run-up to that event, the Brooklyn Library experienced insatiable demand for literature relating to Parsifal. It was reported that books about Wagner could not be kept in the building 'longer than it takes to transfer them from one set of readers to another'. 'Lecturers have been active', added one newspaper, and the opera had been discussed from every perspective, save the religious. That was about to change, however, when the well-known music teacher and Manhattan church organist, Albert Ross Parsons, delivered a speech about Wagner's theology (Anon 1890a:19). This was a reprise of one he had done at an Episcopal church in Manhattan the previous year (vide infra).

It must be emphasised that there was no significant clerical protest against such performances before it was announced that the opera, as such, was presented in New York in 1903. On the contrary, occasionally American Protestants had lauded Wagner's music dramas, especially Parsifal. Well before the end of the century, though hardly as early as their British counterparts, a small number of American clergymen and other prominent Christians began to write books praising Parsifal and interpreting its spiritual themes. Parsons, for example, delivered his inordinately long lecture on that opera and Wagner's theology at All Souls Episcopal Church in Manhattan in 1889 which was subsequently published as a book (Parsons 1890). The rector of that parish, R. Heber Newton (1840-1914) - then one of the most theologically controversial Episcopalians in the country - had been charged with heresy in 1883 but not convicted (Anon 1883a:8). He later became a staunch defender of Parsifal as will be seen below.

An even more noteworthy instance of this clerical support took place in the season of Advent, 1903, that is very shortly before the première in New York. The eminent Congregationalist minister and leading advocate of the Social Gospel Washington Gladden (1836-1918), then still in his long-term pastorate in Columbus, Ohio, delivered the William Belden Nobel Noble Lectures at Harvard University which were subsequently published as Witnesses 
of the Light. He spoke not only about Wagner, but also about Dante Alighieri, Michelangelo, Johann Fichte, Victor Hugo and John Ruskin. To this theologically moderate liberal, Parsifal was 'in some respects the greatest' and 'most deeply religious' of Wagner's dramas. 'In no other work of dramatic art has there been such a serious attempt to incarnate the Christ-idea as in "Parsifal", Gladden (1903:226) generalised. In support of his assertion, he quoted the composer who had explained that in the title character 'the sufferings of the redeemer himself are the saving power' - a statement which could hardly fail to awaken among theologically sensitised Christian listeners an allusion to the atonement of Jesus (Gladden 1903:228).

A third example came from the pen of Oliver Huckel (18641940), a scholarly Congregationalist minister in Baltimore who had studied at the Universities of Berlin and Oxford in the 1890s and who wrote extensively about Wagner over a period of many years. In his book Parsifal, Huckel (1903) described that work as the composer's 'great confession of faith' in which he had used the Holy Grail legend to convey 'wonderfully and thrillingly' Christian truths about 'the beauty, the glory, and the inspiring power of the Lord's Supper' as well as the message of the Cross. Huckel granted that the 'ingenious' criticism, heard on both sides of the Atlantic, that Wagner had essentially become a Buddhist under the influence of Arthur Schopenhauer, may have contained a kernel of truth, as it suggested that 'all great religions in their essence have much which is akin'. This theological liberal defended the composer, however, by stating that his correspondence with his wife, while completing Parsifal, left no doubt that his intention was to express as deeply as possible 'the essentials of Christian truth' (Huckel 1903:xi-xi).

\section{American Protestant hostility to the production}

Clerical hostility to the performance of Parsifal began shortly after the newly appointed director of the Metropolitan Opera - a secular Jew from Vienna named Heinrich Conried (18551909) who had emigrated to the United States of America in 1878 and managed other theatres in New York before taking up his prestigious position in 1903 - announced his intention. Because his adopted country was not yet a signatory to the Berne Convention, which protected intellectual property in much of Europe, he felt at liberty to flout Wagner's widow's wishes that the ban on Parsifal being performed away from Bayreuth be respected. A protracted legal case ensued, but on 24 November an American judge refused to forbid Conried from continuing with his plans to have the long-awaited première a month later.

As a seasoned impersario, Conried exploited the press to promote his costly production. Some observers expressed ardent criticism of what they perceived as manipulation. One of these, the renowned neoclassical sculptor Larkin Mead (1835-1910), who also contributed essays to newspapers, suggested that Conried had orchestrated or, in any case, consciously nurtured the debate about the spiritual dimensions of the performance. Within a few days after the première, he declared, 'Nothing has ever torn up this town as the exploitation of Parsifal'. A part of the responsibility, Mead opined, lay with Wagner's widow, who 'filled the papers with her lamentations'. Her persistent objections had prompted 'a question of Business vs. Ethics', stimulating Conried to 'play his trump card': 'Little by little the religious symbolism of his Parsifal was allowed to filter out', and some of the local clergy responded with cries of sacrilege. This, too, Mead believed, had worked to Conried's advantage. 'We'll see whether it is or not', answered the laity as they rushed to buy tickets (Mead 1903:4).

Mead's acerbic criticism was no doubt hyperbolic, and there is no reason to doubt that numerous Christians in New York and elsewhere were deeply hostile to what they believed was irreverent use of Christian symbolism for entertainment purposes. What is clear is that Protestant clergymen, representing several denominations, reacted with unveiled hostility and cautioned fellow Christians not to attend the performances. One of the spiritual warriors, Reverend George L. Shearer, who led the assault, although only briefly before others played more sustained if equally ineffective roles, was the secretary of the American Tract Society. He was soon joined by other American Protestant clergymen, raised a harmonised voice of protest. 'The play in its three acts centres mainly about the Holy Communion and our Lord Jesus Christ', Shearer contended, but it was 'not sincere worship of the one living and true God. The Lord's Supper cannot be rightly prostituted to such ends' (Anon 1903c:6). No doubt fearing the loss of the considerable investment, which the Metropolitan Opera had already made in the project, Conried diametrically disagreed and dismissed the clergymen's objection out of hand. 'I am of the firm conviction, that there is nothing religious, far less sacrilegious, in the music drama of "Parsifal"', he generalised, adding that 'in Europe the arguments advanced in this statement have been advanced repeatedly and as repeatedly laughed out of court' (Anon 1903c:6).

Conried's assurance failed to disarm his foes. The leadership of the clerical opposition fell on Frederick Burgess (18531925), the Episcopal bishop of Long Island. One of his many verbal assaults was a sermon preached in early December. Without mentioning the opera by name, he caricatured its content by calling the production a result of pagan thought. Burgess summarised many of his objections to the symbolism in the plot, which apparently he perceived as a distorted allegory of the life of Christ:

A characterless fool is represented as the Redeemer and the Saviour, and in an awful mockery His feet are washed by the woman who was a sinner. A representation of the Last Supper of the Son of God is presented on the stage, and words are sung which can only make us shudder. (Anon 1903b:4)

It was all 'sacrilege' and 'unholy', he judged, 'blasphemy against the Holy Ghost'. Burgess's comments rested on the assumption that the eponymous character was in fact a 
symbolic Jesus figure. This left him vulnerable to counterpunching by Conried:

The plot described by Bishop Burgess is so unlike that of 'Parsifal' that I have no right to assume that the Bishop refers to that opera. In 'Parsifal' there is no characterless fool, feeble and scant witted. There is no Christ and the feet of no Saviour are touched, as suggested, by the hair of Mary Magdalene. The Last Supper is not represented on the stage, so the offences enumerated by the Bishop are imaginary. (Anon 1903b:4)

Another prominent Protestant parson in the forefront of the assault on the staging of Parsifal was David J. Burrell of the Collegiate Church in Manhattan. In a last-ditch effort to prevent it, he issued a pamphlet titled Parsifal: A Remonstrance. Therein, Burrell appealed to Mayor Seth Low to revoke the licence which the city had issued permitting the performance in the Metropolitan Opera House. His argument was partly based on his conviction that the United States of America was 'a Christian country' and accordingly there should be 'patriotic protest against this grim display of symbols associated with Christ's life and doctrine, on which our laws and jurisprudence are founded' (Anon 1903a:1, 3). Secularisation had already gone too far in eroding public respect for the faith, Burrell lamented; people routinely profaned the Lord's name and desecrated 'His holy day'. In an allusion to the Last Supper, which he obviously believed was symbolically represented in the grail scene, he admonished readers not to 'stoop so low' as to dignify through their attendance 'an operatic presentation of Christ's farewell interview with His disciples of the sacramental table, His pardoning grace to sinners, or His atoning blood' (Anon 1903a:1, 3). His efforts came to naught; Low refused to intervene.

Generally speaking, Protestant criticisms of Parsifal were characterised by relatively intemperate language and do not betray an intimate knowledge with the text of the drama or experience viewing it at Bayreuth. Moreover, most of them were published before the première. A conspicuous if only partial exception was that offered by Charles Henry Parkhurst (1842-1933) who had served as the pastor of Madison Square Presbyterian Church in Manhattan since 1880. This former Congregationalist minister had also studied at the Universities of Halle and Leipzig. Before entering the pastoral ministry he had been a school teacher and an instructor at a theological seminary. In the early 1890s Parkhurst had gained notoriety by investigating, with the help of a private detective, corruption in the 'Tammany Hall' government of New York and preaching sermons against it.

Apparently in response to a request from the local daily newspaper The World, this well-known cleric wrote 'a brief statement' of his views of Parsifal. Precisely when he did so is unknown; his undated letter appeared in The World the day after the initial performance. Parkhurst assured readers that he had 'read and re-read the libretto with conscientious care' and emphasised that he interpreted it as a man who believed in Jesus Christ 'not simply as a knight or a hero, but as the great God Himself manifest in flesh'. Furthermore, he stated that he chose to: conceive of His blood as having been divinely shed for the remission of sins, and interpret the Lord's Supper in the sense in which the Gospel distinctly represents it, and find in that Supper a Sacrament that phrases the very reality of the life and mission of the God-man, the very innermost heart of God's redemptive purpose and plan.

Having nailed his orthodox Christian views to the mast, Parkhurst put aside moderation and judged 'the thing detestable beyond words of mine to express'. It was, moreover, 'disgraceful to those who participate in any way in its presentation, and sacrilegious on the part of those who go to witness it'; though why that was the case he did not clearly explain. He even threw restraint to the four winds and indicted the decision to produce Parsifal was:

a pretty faithful imitation of the act of Judas Iscariot, who traded on the Lord's blood, to the winning of thirty pieces of silver: and so far as relates to those who go to witness the performance, it is their silver that motives the Judas traffic.

This pastoral nurturer of Christian spirituality seemed particularly incensed at what struck him as cheap, artificial piety on the stage. The Lord's Supper, Parkhurst asserted without explanation, was in fact represented in the drama, alongside a 'stagy affectation of prayer'. It was all contrived 'to delight the aesthetic sense' by blending religion with 'trombones, evening bells, fading light, [and] dissolving views' and 'with just a delicate spicing of libidinousness, maybe instinct with the power to please'. In this amalgam, Parkhurst declared that the 'essential sacrilegiousness of the exhibition' was camouflaged into virtual invisibility. Defenders of the artistic representation of sacred elements of the Gospel, he argued, stood on infirm ground. To Parkhurst, their contention that the 'dramatic illusions [sic] to the blood and the Supper' were primarily references to 'old legends that have been forever floating in the dreamy brain of man universal' were only 'wheedling stuff and nonsense' which would not impress 'the moral and evangelical sense' of individuals who were familiar with both legend and essential Christianity (Anon 1903e:9). His poorly argued 'brief statement' revealed more about his own attitude than it did about Parsifal.

\section{Diverse laymen's responses}

Like the clergy, lay people were divided in their published attitudes towards the première of Parsifal. As would be the case in England in 1914, letters to editors cropped up in many newspapers. Some commented on the illogic and alleged hypocrisy inherent in religious leaders' criticisms. One who identified himself only as 'A.R.' wrote to The Sun in New York accusing members of the clergy who had a 'confused conception' of the work of bewildering 'the minds of their congregation[s]' about its meaning. In a crass contortion of complex cultural history he suggested they bear in mind that a major root of the forms of Christian worship was classical Greek drama, conveyed through medieval miracle plays which, mutatis mutandis, had also led to modern dramas. In another thread of oversimplification, A.R., apparently under 
the false impression that the criticisms had been of religion in general represented on the stage or in other art forms, took the 'objecting clergymen' to task for attending performances of Händel's Messiah and going to museums to view paintings of the nativity and crucifixion of Jesus. 'If these gentlemen were consistent', he reasoned, 'they should object to any form of art or poetry treating the subjects which they claim as sacred'. The root of their problem, A.R. theorised, lay in an 'iconoclastic' and 'Calvinistic' spirit which had sought to eradicate 'all Church ceremonial' from worship and even 'refused to recognize the dogma of transubstantiation in connection with the mass and communion service'. ${ }^{2}$

Writing from Philadelphia, meanwhile, 'J.T.' lent his support to Burrell, Burgess, and other men of the cloth in their opposition to Parsifal. He had recently attended in that city an illustrated lecture by an unidentified lady who had alternated 'pleasing' pictures from the opera with paintings depicting scenes in the Bible while Wagnerian music was played in the background. The lecturer had sought to obviate severe reactions by making prefatory comments to the audience, but these had failed to placate J.T. He thought one would inevitably perceive 'the close connection between the persons and things represented and the person and things which we consider most holy'. They were 'practically the same', he concluded, 'and caused one to shudder at the profanity of the drama, and to realize that we are indeed living in irreverent times'. ${ }^{3}$

\section{R. Heber Newton: Constructing a temple to Wagner?}

Richard Heber Newton, the theologically very liberal rector of All Souls Church in Manhattan, responded to current operatic fervour by hastily completing his book Parsifal: An Ethical and Spiritual Interpretation very early in 1904. Speaking to the New York Chapter of the Actors' Church Alliance in February, he (Newton 1904) stated that he had attended two performances of 'the great drama' but not been fully satisfied with the setting in which it had been given. Newton shared his perception that a 'spirit of deep reverence' had prevailed, but acknowledged that some observers had understandably been sceptical that a spiritual work of that magnitude 'would be profaned by being taken from the land of poverty and philosophy to the land of materialism and Mammon'. He proposed that a specifically dedicated opera house be erected to provide a fully appropriate setting 'for productions of such grandeur and beauty and power as "Parsifal"'. A 'temple' of that sort, Newton believed, would mark 'the consecration of the stage to its coming mission and ministry in the service of moral and religious progress' (Anon 1904b:8).

\section{American Catholic reactions}

Broadly speaking the staging of Parsifal in New York did not elicit nearly the hostility among American Catholics as it did 2.A.R. (New York) to The Sun, 21 December 1903, in The Sun, 23 December 1903, p. 2. 3.J.T. (Philadelphia) to The Sun, 21 December 1903, in The Sun, 23 December 1903, p. 6. among their Protestant compatriots. However, on both sides there was no consensus among the reactions. No more than in the United Kingdom had Catholics in the United States ever maintained a united front against this opera. In fact, a decade earlier Catholics in the New York Archdiocese had arranged a concert at Music Hall in midtown Manhattan as part of the festivities in honour of the 15th anniversary of the accession of Leo XIII to the Holy See and included the Prelude to Parsifal in programme which also featured works by Palestrina, Händel and Liszt (Anon 1893:2).

It is impossible even to estimate how many priests and other Catholics expressed opinions of Parsifal. What is clear, however, is that some in New York attended the performances and encouraged co-religionists to do likewise. Among the more prominent of these men was Father John Talbot Smith (1855-1923), who was not then serving as a priest but had keen literary interests and written $A$ Woman of Culture and several other novels. He had previously edited the Catholic Review and would later help to found the Catholic Actors' Guild of America (Anon 1914b:7; 1923:8). Interviewed in early December, Smith declared that the forthcoming production was prompting him 'in future to pay steady attention to opera'. He disagreed with detractors who had 'loosely described' the grail ritual in Act One as a representation of the Last Supper. Smith (Anon 1903d:10) judged that, 'There is no Last Supper and no sacrament on the stage ... What will be seen is merely the symbolism of the Holy Grail, which is a myth'. He predicted that the scene would prove gratifying and not 'distasteful to reflecting Catholics' (Anon 1903d:10).

By no means did Smith stand alone in offering Catholic clerical support to Parsifal. The New-York Tribune reported that the day before the première, Father Alexander Doyle (1857-1912), who headed the Paulist Fathers in New York, had attended a rehearsal and subsequently sent Conried an enthusiastic letter assuring him that he had enjoyed the first act (which included the grail ritual) 'and found it devoutly reverent and inspiring'. According to the same newspaper, an unspecified number of 'other priests' attended the opening performance and 'did not condemn the production' (Anon 1903f:2).

Other Catholics elected to keep their distance. Among them were the Filiae Fidei [Daughters of the Faith], who were described in the Irish-American press as 'a remodeled society composed of Catholic women' and announced that their goals were 'to discountenance such productions as "Parsifal"', prevent 'the wearing of decolete [sic] gowns below the line of moderation', and oppose 'all other things not consistent with the lives of practical Catholic women' (Anon 1904a:2). At one of their first meetings the 'Daughters' had been addressed by the 'Jesuit orator' William O'Brien Pardow (1847-1909), who effectively admonished them not to attend any performances of Parsifal. They announced that their 'dramatic and literary committees' would examine new plays and offer opinions about their appropriateness for viewing by Catholic women (Anon 1904a:2). 


\section{Conclusion}

Considered from the perspective of church history, the dispute over Parsifal at the Metropolitan Opera within the broader context of American and British public reactions yields observations about the state of organised Christian life during a period of rapid transition in many aspects of religious life generally. Obviously, the protests, which chiefly Protestant clergymen but also a smaller number of Catholics mounted in the hope of either preventing Conried from putting the opera on the stage or at least convincing most people to boycott it, were ineffective. Parsifal attracted enormous interest and throngs of viewers, many of whom travelled from Chicago and other Midwestern cities to attend the performances. The foes apparently overestimated their sway. On the one hand, numerous clergymen in several denominations lamented the secularisation which they perceived in American society and saw in Parsifal an unmistakable manifestation of it. The fact that its première should fall on Christmas Eve in an opera house managed by a Jewish immigrant bolstered their perception that whatever salad days Christianity had enjoyed in American society were rapidly fading into the past. On the other hand, despite their consciousness of this loss of status, they quite unrealistically imagined that they somehow still had the moral clout to prevent the staging of an enormously popular and internationally renowned opera for which the American public had waited more than two decades to experience.

Obviously, it is impossible to ascertain how many people men like Burgess, Parkhurst, Burrell, Pardow and Shearer deterred from attending. By all accounts, however, Conried and his colleagues had no difficulty selling large numbers of tickets not only in December, but also to the performances early in 1904. The conviction that the United States was a 'Christian country', notwithstanding the fact that in the year 1900 fewer than $50 \%$ of its population were church members while the majority had no official religious affiliation (Gaustad \& Barlow 2000:349), continued as a Leitmotiv, not only in religious writing and homiletics, but also in political rhetoric, throughout much of the 20th century - although during its last few decades an additional element of religious pluralism became a standard part of much of that oral tradition in many quarters.

Parsifal, too, became a fairly standard repertoire in American musical performance as the older tradition of performing it as an oratorio gave way to its staging, usually in English translation, as a drama after Conried's seminally successful breaking of the ban. As Katherine R. Syer has noted, before the end of 1904 the Henry Savage English Grand Opera Company had staged it more than 200 times in a gruelling schedule. This figure approximated the total number of Parsifal performances at Bayreuth from 1882 until 1933 (Syer 2005:282-283). On American shores, its popularity was interrupted by the First World War (1914-1918) but revived after the armistice. It is conceivable, of course, that Christian clergy and lay people never fully gave up their misgivings, but the public record does not indicate that the full-scale protests, which were made against the initial Conried production, replicated themselves.

At the outset we asked what the controversy, surrounding the New York première of Parsifal, reveals about the relationship between Christianity and the arts in American society during that era when urban society was growing rapidly, the Christian faith still commanded much public respect, and operatic performances served as one of many cultural bridges to Europe, albeit for only a small percentage of the population. One can tentatively conclude that there is a low ceiling on the revelation. The debates rarely ascended to a lofty intellectual altitude; they tended to be sketchy and truncated, and the language in which they were carried out was generally polemical and sweeping rather than detailed. The verbal combatants certainly did not broach such matters as Wagner's possible indebtedness to Schopenhauer or Buddhism. What seems beyond dispute, however, is that among many clergymen and lay people of various denominational hues there was a remarkable hostility to the use of religious themes in public entertainment, while other Christians, both lay and ordained, had more tolerant attitudes and believed that the arts could serve as effective vehicles for communicating spiritual truths. However, for more detailed considerations of Parsifal in this regard one must go beyond the public disputes before and during the Metropolitan Opera House season and peruse books by Huckel, Gladden and others who analysed the work from their generally liberal theological perspectives and commended it to their readers. That related topic lies outside the scope of the present article but merits a detailed study of its own.

Finally, as an appendage to the history of Christian theology, although the number of verbal combatants in the debate was too small to allow broad generalisation, it is conspicuous that among the Protestants those who were known to be theologically liberal in the context of that era such as Newton and Huckel, there was a willingness to perceive in Parsifal a spiritually useful artistic representation of Christian truths. On the other hand, among their more conservative colleagues who protested, this was conspicuously less the case.

\section{Acknowledgements Competing interests}

The author declares that he has no financial or personal relationships which may have inappropriately influenced him in writing this article.

\section{References}

Anon., 1881a, 'Music', The Graphic (London), 3 September, p. 24.

Anon., 1881b, 'Notes from the Athenæum', Edinburgh Evening News, 21 October, p. 3.

Anon., 1882a, 'Music', The Sunday Times (London), 29 October, p. 7.

Anon., 1882b, 'Music and the drama', The Glasgow Herald, 30 October, p. 8.

Anon., 1882c, 'The oratorio society', The New York Times, 8 November, p. 4.

Anon., 1882d, 'The Wagner festival', The New York Times, 27 July, p. 3.

Anon., 1883a, 'Charged with heresy: A presentment against the rev. R. Heber Newton', The New York Times, 26 April, p. 8.

Anon., 1883b, 'Richard Wagner', The Tablet 61(2237), 13-14. 
Anon., 1884a, 'Metropolitan Gossip', The Belfast News-Letter, 20 November, p. 7. Anon., 1884b, 'Music. Wagner's "Parsifal"', The Sunday Times (London), 16 November, p. 7. Anon., 1884c, 'Wagner's "Parsifal" at the Albert-hall', The Times (London), 10 November, p. 10.

Anon., 1886a, 'Announcements. The Oratorio Society', The Sun (New York), 5 March, p. 2. Anon., 1886b, '“Parsifal” as an Oratorio', New-York Daily Tribune, 5 March, p. 4.

Anon., 1890a, “'Parsifal” in Brooklyn', The Sun (New York), 23 March, p. 19.

Anon., 1890b, 'A play and some operas', The Sun (New York), 1 April, p. 5.

Anon., 1893, 'In the Pope's Honor. A grand concert to be given in celebration of his jubilee', The Irish-American (New York), 18 February, p. 2.

Anon., 1903a, 'Asked to stop Parsifal', New York Tribune, 19 December, pp. 1, 3.

Anon., 1903b, 'Bishop denounces Parsifal', The Sun (New York), 4 December, p. 4.

Anon., 1903c, 'Object to "Parsifal"', The New York Times, 11 November, p. 6.

Anon., 1903d, 'Opera triumph', Boston Daily Globe, 25 December, p. 10.

Anon., 1903e, “'Spare Us," says bishop', New-York Daily Tribune, 5 December, p. 9.

Anon., 1903f, 'Stupid sacrilege, says Dr. Parkhurst', The World (New York), 25 December, p. 2.

Anon., 1904a, 'Daughters of the faith', The Irish World and American Industria Liberator (New York), 23 January, p. 2.

Anon., 1904b, 'For new world Baireuth. Dr. Newton urges a temple for Wagner usicdrama', The New York Times, 15 February, p. 8.

Anon., 1914a, 'The audience at "Parsifal”', The Times (London), 6 February, p. 7.

Anon., 1914b, 'Catholic guild of actors is organized', The Sun (New York), 6 April, p. 7.

Anon., 1923, 'Untitled obituary', The New York Times, 25 September, p. 8.

Beckett, L., 1981, Richard Wagner: Parsifal, Cambridge University Press, Cambridge.

Briggs, H.E., 1989, 'Richard Wagner and American music-liberary activity from 1850 to 1920 ', PhD thesis, Indiana University, Bloomington.
Eaton, Q., 1968, The miracle of the met: An informal history of the Metropolitan Opera 1883-1967, Meredith Press, New York.

Forsyth, P.T., 1889, Religion in recent art: Being expository lectures on Rossetti, BurneJones, Watts, Holman Hunt and Wagner, Abel Heywood \& Son, Manchester.

Gatty, C.T., 1894, The sacred festival-drama of Parsifal, Scott and Co., London.

Gaustad, E.S. \& Barlow, P.L., 2000, New historical atlas of religion in America, Oxford University Press, New York.

Gladden, W., 1903, Witnesses of the light: Being the William Belden Noble Lectures for 1903, Houghton, Mifflin and Company, Boston, MA.

Gurney, A., 1888, Parsifal: A festival play by Richard Wagner, Kegan Paul \& Co., London.

Hale, F., 2013, "'Fundamentalism", and "Fundamentalist" semantically considered: Their lexical origins, early polysemy and pejoration', In die Skriflig/In Luce Verbi 47(1), Art. \#672, 8 pages. https://doi.org/10.4102/ids.v47i1.672

Horowitz, J., 1994, Wagner nights: American history, University of California Press, Berkeley, CA.

Huckel, O., 1903, Parsifal, Thomas P. Crowell \& Co., New York.

Kinderman, W. \& Syer, K.S. (eds.), 2005, A companion to Wagner's Parsifal, Camden House, Rochester, NY.

Krehbiel, H.E., 1908, Chapters of opera, Henry Holt \& Company, New York.

Mead, L.G., 1903, 'New York has heard Wagner's "Parsifal"', The Tacoma Times, 28 December, p. 4.

Newton, R.H., 1904, Parsifal: An ethical and spiritual interpretation, Upland Farms Alliance, Oscawana-on-Hudson, NY.

Parsons, A.R., 1890, Parsifal: The finding of Christ through art; or, Richard Wagner as a Theologian, G.P. Putnam's Sons, New York.

Sessa, A.D., 1979, Richard Wagner and the English, Fairleigh Dickinson University Press, Rutherford, NJ.

Syer, K.R., 2005, 'Parsifal on stage', in W. Kinderman \& K.R. Syer (eds.), A companion to Wagner's Parsifal, pp. 277-351, Camden House, Rochester, New York. 